Animal Health Research Institute,

Damanhour Branch.

\title{
DETERMINATION OF SODIUM NITRITE IN SOME LOCALLY MANUFACTURED MEAT PRADUCTS
}

(With 3 Tables and One Figure)

\author{
By
}

\section{I.A. EL-KEWAIEY and F.A. AL-TEDAWY}

(Received at 15/12/2011)

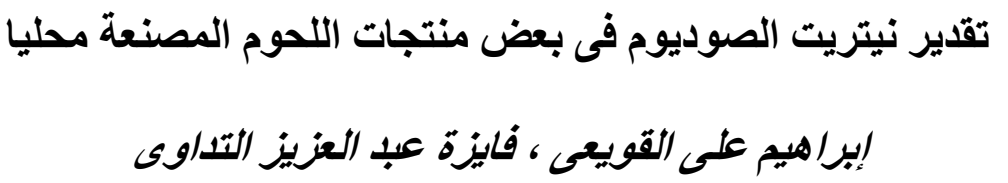

تعتبر اللحوم المحفوظة بمادة نيتريت الصوديوم من أكثر منتجات اللحوم انتشار اللدى الغالبيـة

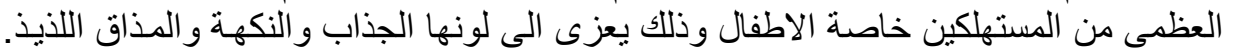

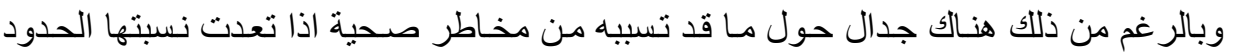

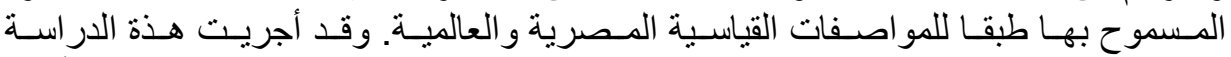

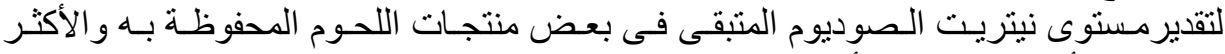

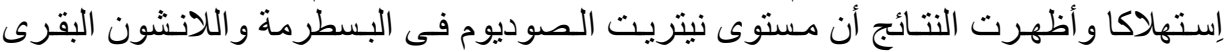

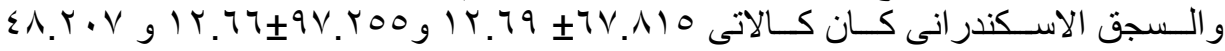

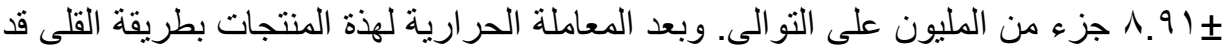

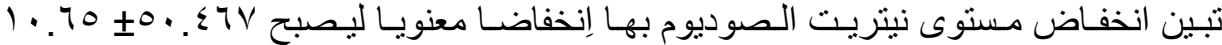

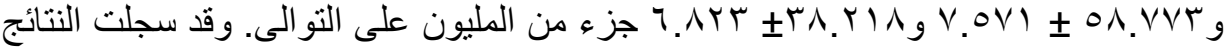

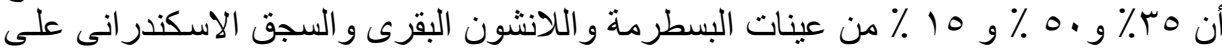

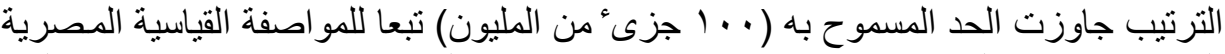

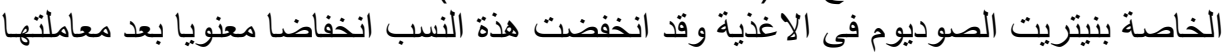

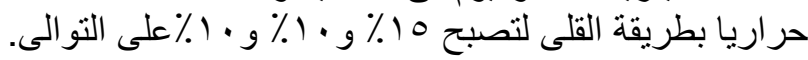

\section{SUMMARY}

Cured meat constitute the large proportion of the processed meats favoured by the great majority of the consumers especially the children due to its attractive colour, flavour, palatable and moreover its delicious taste. Despite of benefits and multi-functional properties of sodium nitrite,it has been often a source of doubt due to its health hazards. This study was conducted to investigate the residual level of nitrite in the 
most popular cured meat products retailed in food outlets. The results revealed that the residual nitrite levels in prifried pastirma, beef luncheon and Alexandria semi-dry sausage were $67.815 \pm 12.69$, $97.255 \pm 12.66$ and $48.207 \pm 8.91 \mathrm{ppm}$, respectively. After frying of these products, the estimated values of nitrite were significantly decreased and the means \pm S.E.values were recorded as $50.467 \pm 10.65,58.773 \pm 7.571$ and $38.218 \pm 6.823 \mathrm{ppm}$, respectively. $35 \%, 50 \%$ and $15 \%$ of retailed pastirma, beef luncheon and semi-dry sausage were exceeded the Egyptian maximum permissible limits (100ppm) but after frying these percentages were decreased significantly to $15 \%, 10 \%$ and $10 \%$, respectively.

Key words: Meat products, sausage, luncheon, pastirma, sod.nitrite.

\section{INTRODUCTION}

Meat is the main source of animal protein essential for human nutrition.Curing of meats as a method of preservation would help in diminishing perishability and improves palatability and increases its shelf-life.

The usual processing of cured meat is to incorporate sodium chloride, sodium nitrite, a reducing agent (such as ascorbate) and other ingredients such as seasonings (Kramlich et al., 1973). The result is a meat product with a characteristic pink colour and with a specific flavour. Because of the curing ingredients, the heat processing and the usual use of vacuum packaging, the product will maintain freshness and safety for several weeks with assuming a proper refrigeration chain.

Present-day consumers have an intense interest in health, as related to food consumption patterns and especially to the intake of meat. Two components of cured meats have come under withering attack, fat and sodium nitrite. Composition of cured meats, especially emulsion products, has changed greatly in the past decades. The changes have been driven by consumer demand for low-fat products. While the allowable fat content is basically $\leq 30 \%$, they have been altered so that products containing 1 to $5 \%$ are now commonly available. The distress about fat has been its possible association with diseases of the heart and circulatory system and also with a tendancy to some forms of cancer (Cassens, 1997). 
Sodium chloride levels added in meat preservation may vary between 3 and $6 \%$ although this is not high enough to exert a complete bacteriostatic action. Therefore, other preservation techniques such as refrigeration, dehydration, acidification, cooking and smoking are required. On the other hand, salt may cause undesirable effects in that it may accelerate oxidation of meat pigments and fats, resulting in brown off colour and rancid taste. Nitrite plays an important role in the prevention of these changes (Muller, 1991; Flores and Toldrá, 1993). Most commercially cured meats are not heated sufficiently to kill the heat resistant bacterial spores such as those of Clostridum botulinum, a food poisoning microorganism, but they have had an excellent safety record. The suggestion of the microbiological safety of such heat processed meat products may be due to the "Perigo factor" an inhibitor of bacteria, that is formed when nitrite is heated (Perigo et al., 1967) and by the reaction of nitrite with sulfhydryls and iron (Moran et al., 1975). Nitrate may be added as sodium or potassium salts which is transformed to nitrite by the bacteria, naturally present in foods or added as a starter culture, which have nitrate reductase activity. The nervousness about nitrite has centered on the potential link to cancer. Because nitrite can exert acute toxic effects and contribute to the total body burden of $\mathrm{N}$ nitroso compounds, it has been recommended that exposure to these agents should be reduced. The use of nitrate salts in curing should be eliminated, with the exception of dry-cured products, due to the great uncertainty of convertion of nitrate to nitrite (Cassens, 1995). The absorbed nitrite in the blood may oxidized haemoglobin to methaemoglobin, thereby reducing or destroying its oxygen carring ability "methaemoglobinemia" (Cassens, 1997). Two subpopulations are known to be more susceptable to methaemoglobinemia, young infants have a high gastric $\mathrm{pH}(\mathrm{pH}>4)$ and thus any ingested nitrite is less rapidly degraded in the stomach and also have lower concentrations of oxidation agents as ascorbic acid in their stomachs to inhibit the reduction of nitrates to nitrites. Individuals suffering from anemia are the second subpopulation that may be more susceptible to methaemoglobinemia because of their lower baseline oxygen-carrying capacity (McKnight et al., 1999). Thus, this study was conducted to monitor the residual nitrite concentrations in the most popular meat products, pastirma, beef luncheon and Alexiandria semi-dry sausage, in retailed and fried states, retailed in El-Bohiera governorate to ensure their quality and safety. 


\section{MATERIALS and METHODS}

\section{Samples collection:}

A total of 60 randomly collected meat products samples (20 each of pastirma, Beef luncheon and Alexandria semi-dry sausage) were purchased from Damanhour supermarkets during the summer of 2010. Each sample of $250 \mathrm{~g}$ weight was placed separately into polyethylene plastic bag, identified and then delivered as soon as possible to the laboratory in an ice box.

\section{Chemical examination:}

\subsection{Preparation of the samples:}

Samples of pastirma and beef luncheon were sliced into thick slices and the semi-dry sausages into several unites. Then, the weight of each sample was halved into 2 portions. The first half was analysed directly and the second portion was fried in a preheated uncovered frying pan using corn oil at $176^{\circ} \mathrm{C}$ until an internal temperature of $76^{\circ} \mathrm{C}$ was reached as monitored by hand thermometer (about 2 minutes).

2.2. Quantitative determination of nitrite levels: by Griess-1losvay reaction (AOAC, 1990).

\subsection{1: Reagents:}

a- Modified Griess-llosvay reagent:weigh $0.5 \mathrm{~g}$ sulphanilic acid and $0.1 \mathrm{~g}$ $\mathrm{N}-1$-naphthyl ethylenediamine dihydrochloride and dissolved in $300 \mathrm{ml}$ $15 \% \mathrm{v} / \mathrm{v}$ acetic acid. Mix with a stirrer to dissolve. Store in a browncoloured glass bottle.

b- Saturated mercuric chloride: weigh $6.9 \mathrm{~g} \mathrm{HgCl}_{2}$ in a $250 \mathrm{ml}$ beaker, dissolve in $100 \mathrm{ml}$ distilled water, then mixing for $1 \mathrm{~h}$. Add more $\mathrm{HgCl}_{2}$ if necessary to ensure saturation.

c- Standardised sodium nitrite stock solution:weigh $0.5 \mathrm{~g}$ dried $\mathrm{NaNO}_{2}$ and dissolve in $1000 \mathrm{ml}$ distilled water, mix. $\left(1 \mathrm{ml}=500 \mu \mathrm{g} \mathrm{NaNO}_{2}\right)$.

d- Standardised sodium nitrite working solution: Transfer $10 \mathrm{ml}$ of stock $\mathrm{NaNO}_{2}$ solution with a volumetric pipette to a $1000 \mathrm{ml}$ volumetric flask. Dissolve and make up to volume with distilled water and mix. $(1 \mathrm{ml}=5 \mu \mathrm{g}$ $\mathrm{NaNO}_{2}$ ).

\subsubsection{Procedure:}

\section{a- Prepartion of standard curve:}

I. Prepare working standards from the dilute standard solution of $\mathrm{NaNO}_{2}$ following the table below to seven $50 \mathrm{ml}$ volumetric flasks, using volumetric pipettes to transfer aliquots. 
Flask Volume dilute standard (ml) Final concentration $\left(\mu \mathrm{g} \mathrm{NaNO}_{2} / \mathrm{ml}\right.$

$\begin{array}{lll}1 & 0 & 0 \\ 2 & 2 & 2 \\ 3 & 3 & 0.30 \\ 4 & 4 & 0.40 \\ 5 & 5 & 0.50 \\ 6 & 10 & 1.00 \\ 7 & 20 & 2.00\end{array}$

II. Fill each flask to $3 / 4$ full with distilled water and mix. Then add $2 \mathrm{ml}$ Griess-llosvay reagent to each flask. Dilute to volume with distilled water and mix.

III. Allow the standards to stand $1 \mathrm{~h}$ to allow maximum colour development. Measure and record the absorbance on a spectrophotometer at 540nm against the reagent blank.

\section{b. Sample preparation and analysis:}

I. Weigh $10.00 \mathrm{~g}$ of meat product into a $150 \mathrm{ml}$ beaker. Add approximately $50 \mathrm{ml} \mathrm{D.W}$. Heat on a hot plate, boil forl-2 min., stirring with a glass rod to break up the sample.

II. Quantitatively transfer sample and dilute to a $250 \mathrm{ml}$ vol. flask. Add $5 \mathrm{ml} \mathrm{HgCl} 2$ to clarify the extract. Mix. and filter through nitrite free filter paper, the filtrate must be free from turbidity.

III. With a vol.pipette transfer a $25 \mathrm{ml}$ aliquot of the filtrate to a $50 \mathrm{ml}$ vol. flask. Fill the vol. flask to $3 / 4$ full with D.W. and mix. Add $2 \mathrm{ml}$ Griess-llosvay reagent. Dilute to volume with D.W. and mix.

IV. Allow the sample to stand $1 \mathrm{~h}$ to allow maximum colour development. Measure and record the absorbance on a spectrophotometer at $540 \mathrm{~nm}$ against a reagent blank.

\section{Calculation:}

I. Calculate the slope of the standard curve:

$\mathrm{m}=[(\mathrm{A} 2 / 0.20)+(\mathrm{A} 3 / 0.30)+(\mathrm{A} 4 / 0.40)+(\mathrm{A} 5 / 0.50)+(\mathrm{A} 6)+(\mathrm{A} 7 / 2.0)] / 6$

where: $\mathrm{A} 2, \mathrm{~A} 3, \mathrm{~A} 4, \mathrm{~A} 5, \mathrm{~A} 6, \mathrm{~A} 7=$ the absorbance of the working standards at $540 \mathrm{~nm}$.

II. Calculate $\mathrm{NaNO}_{2}$ concentration in examined samples:

$$
\left(A_{s}\right)(1 / m)(50)(250)
$$

\footnotetext{
$\mu \mathrm{g} \mathrm{NaNO}{ }_{2} \mu / g=\frac{}{\text { (Volume aliquot) (Sample weight) }}$
} 
Where: $\mathbf{A}_{\mathbf{s}_{\mathbf{~}}}$ is sample absorbance $; \mathbf{m}$ is the slope of the standard curve (assume the slope is linear); $\mathbf{5 0}$ is the volume of the volumetric flask; $\mathbf{2 5 0}$ is the volume of meat product sample extract; volume aliquot is the volume of filtrate.

\section{Standard calabiration curve:}

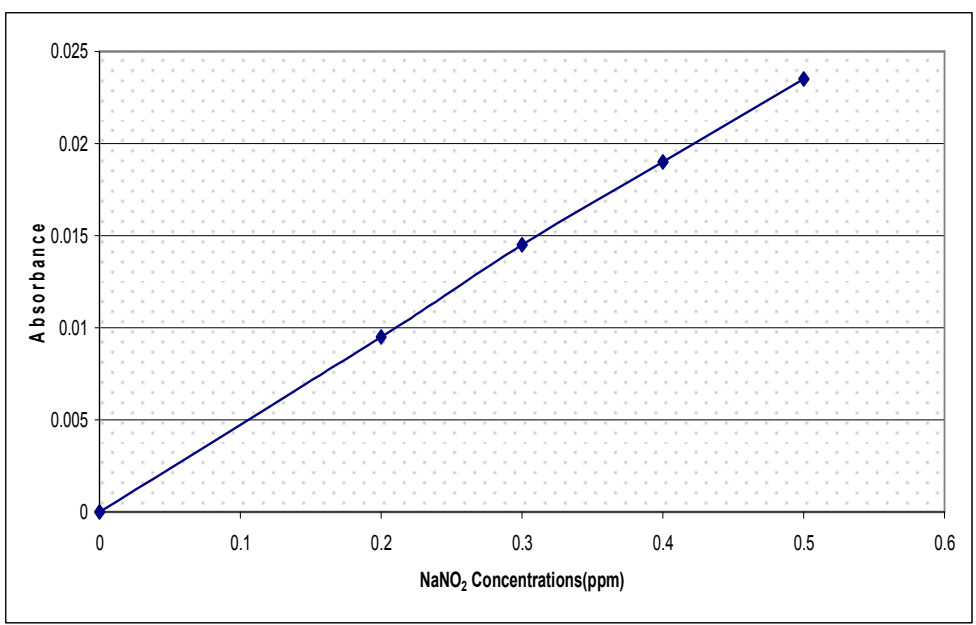

\section{RESULTS}

Table 1: Statistical analytical results of residual nitrite levels (expressed as ppm of sodium nitrite) in examined meat products ' $(n=20$ of each).

\begin{tabular}{|c|c|c|c|c|c|c|c|c|c|c|}
\hline \multirow{3}{*}{ Product Type } & \multicolumn{5}{|c|}{ Before Heat Treatment } & \multicolumn{5}{|c|}{ After Heat Treatment } \\
\hline & \multicolumn{2}{|c|}{$\begin{array}{l}\text { Detected } \\
\text { Samples }\end{array}$} & \multirow{2}{*}{ Min. } & \multirow{2}{*}{ Max. } & \multirow{2}{*}{$\begin{array}{l}\text { Mean } \\
\pm \text { S.E. }\end{array}$} & \multicolumn{2}{|c|}{$\begin{array}{l}\text { Detected } \\
\text { Samples }\end{array}$} & \multirow{2}{*}{ Min. } & \multirow{2}{*}{ Max. } & \multirow{2}{*}{$\begin{array}{l}\text { Mean } \\
\pm \text { S.E. }\end{array}$} \\
\hline & No & $\%$ & & & & NO & $\%$ & & & \\
\hline Pastirma & 20 & 100 & 5.257 & 171.379 & $\begin{array}{l}67.815 \\
\pm 12.69\end{array}$ & 20 & 100 & 1.051 & 166.121 & $\begin{array}{l}50.467 \\
\pm 10.65\end{array}$ \\
\hline $\begin{array}{c}\text { Beef } \\
\text { Luncheon }\end{array}$ & 20 & 100 & 31.542 & 200.818 & $\begin{array}{l}97.255 \\
\pm 12.66\end{array}$ & 20 & 100 & 14.72 & 150.35 & $\begin{array}{l}58.773 \\
\pm 7.571\end{array}$ \\
\hline $\begin{array}{l}\text { Semi-dry } \\
\text { Sausage }\end{array}$ & 20 & 100 & 6.308 & 139.836 & $\begin{array}{c}48.207 \\
\pm 8.91\end{array}$ & 20 & 100 & 6.308 & 103.037 & $\begin{array}{c}38.218 \\
\pm 6.823\end{array}$ \\
\hline
\end{tabular}

Min. $=$ Minimum Max. $=$ Maximum S.E. $=$ Standard Error of Mean 
Table 2: Frequency distributions of nitrite levels in examined meat products*.

\begin{tabular}{|c|c|c|c|c|c|c|c|c|c|c|c|c|}
\hline \multirow{3}{*}{$\begin{array}{l}\text { Levels } \\
\text { ranges }\end{array}$} & \multicolumn{4}{|c|}{ Pastirma } & \multicolumn{4}{|c|}{$\begin{array}{c}\text { Beef } \\
\text { Luncheon }\end{array}$} & \multicolumn{4}{|c|}{$\begin{array}{l}\text { Semi-dry } \\
\text { Sausage }\end{array}$} \\
\hline & \multicolumn{2}{|c|}{ Before H.T. } & \multicolumn{2}{|c|}{$\begin{array}{l}\text { After } \\
\text { H.T. }\end{array}$} & \multicolumn{2}{|c|}{$\begin{array}{c}\text { Before } \\
\text { H.T. }\end{array}$} & \multicolumn{2}{|c|}{$\begin{array}{l}\text { After } \\
\text { H.T. }\end{array}$} & \multicolumn{2}{|c|}{$\begin{array}{c}\text { Before } \\
\text { H.T. }\end{array}$} & \multicolumn{2}{|c|}{$\begin{array}{l}\text { After } \\
\text { H.T. }\end{array}$} \\
\hline & No & $\%$ & No & $\%$ & No & $\%$ & NO & $\%$ & No & $\%$ & & $\%$ \\
\hline ND & 0 & 0 & 0 & 0 & 0 & 0 & 0 & 0 & 0 & 0 & 0 & 0 \\
\hline $1-25$ & 7 & 35 & 7 & 35 & 0 & 0 & 2 & 10 & 5 & 25 & 7 & 35 \\
\hline$>25-50$ & 4 & 20 & 7 & 35 & 7 & 35 & 7 & 35 & 10 & 50 & 9 & 45 \\
\hline$>50-75$ & 1 & 5 & 1 & 5 & 3 & 15 & 6 & 30 & 0 & 0 & 1 & 5 \\
\hline$>75-100$ & 1 & 5 & 2 & 10 & 0 & 0 & 3 & 15 & 2 & 10 & 1 & 5 \\
\hline$>100-125$ & 4 & 20 & 1 & 5 & 3 & 15 & 1 & 5 & 1 & 5 & 2 & 10 \\
\hline$>125-150$ & 1 & 5 & 0 & 0 & 4 & 20 & 0 & 0 & 2 & 10 & 0 & 0 \\
\hline$>150-175$ & 2 & 10 & 2 & 10 & 0 & 0 & 1 & 5 & 0 & 0 & 0 & 0 \\
\hline$>175-200$ & 0 & 0 & 0 & 0 & 2 & 10 & 0 & 0 & 0 & 0 & 0 & 0 \\
\hline$>200-225$ & 0 & 0 & 0 & 0 & 1 & 5 & 0 & 0 & 0 & 0 & 0 & 0 \\
\hline
\end{tabular}

H.T. $=$ Heat treatment $\quad$ P.L. $=$ Permissible limit $\quad$ No $=$ Number $\mathbf{N D}=$ Not detected

* P.L.= permissible limit according to Egyptian Standard Specification (E.S.S.)

No. $\quad 3597 / 2005$ for sodium nitrite used in foods products=100ppm. 


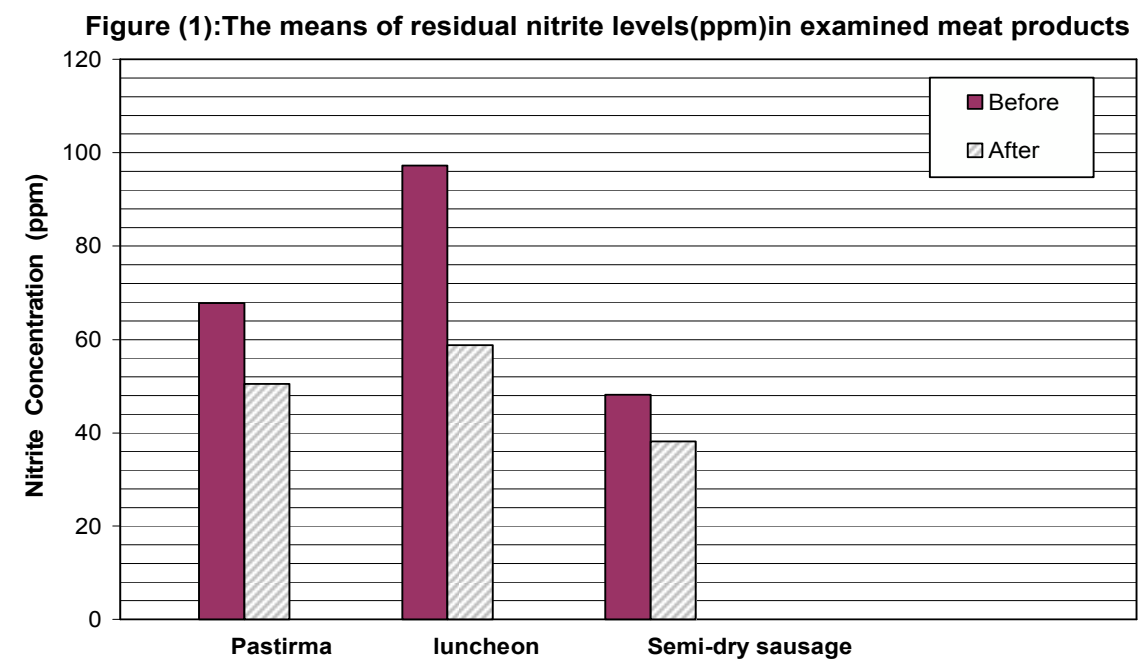

Table 3: Statistical analytical results by using paired t-test.

\begin{tabular}{|l|c|c|c|c|}
\hline $\begin{array}{c}\text { Statistic } \\
\text { parameters }\end{array}$ & Calculated"t"value & df & $\begin{array}{c}\text { Means } \\
\text { differance }\end{array}$ & $\begin{array}{c}\text { Significane } \\
\text { "P value" }\end{array}$ \\
\hline Product & 2.341 & 19 & 17.348 & 0.030 \\
\hline Beef luncheon & 4.210 & 19 & 38.481 & 0.0005 \\
\hline Semi-dry sausage & 2.330 & 19 & 9.988 & 0.031 \\
\hline
\end{tabular}

Significance level at $5 \%$

\section{DISSCUSION}

The function of nitrite in meat curing is four folds: To stabilize the colour of the lean tissues, to contribute to the characteristics flavour of cured meat, to inhibit growth of a number of anaerobic food poisoning and spoilage microorganisms and to retard development of rancidity (Pearson and Tauber, 1996). The most 
important action of nitrite is the preventing of the growth of Cl.botulinum and its toxins. Moreover, Wirth (1991) realized that up till now no substance has been found and don't expect that any will be found that could take the place of nitrite with its varied actions in meat products. Nitrites have effects on microorganisms other than Cl.botulinum. They have proven to have inhibitory effects against Cl.perfringens, $\quad$ E.coli O157:H7, Listeria monocytogens, Achromobacter, Enterobacter, Flavobacterium, Micrococcus and Pseudomonas (Tarr, 1942; Gibson and Roberts, 1986; Pelroy et al., 1994) certain strains of Salmonella, Bacillus and Clostridum are resistant (Rice and Pierson, 1982).

\section{Pastirma:}

The obtained results in Table 1 showed that the residual nitrite levels (ppm) in examined prifried samples of pastirma were ranged from 5.257 to171.379 with a mean \pm S.E.value of $67.815 \pm 12.69 \mathrm{ppm}$; while after frying were ranged from 1.051 to166.121 with a mean \pm S.E. value of $50.467 \pm 10.65 \mathrm{ppm}$.

Higher results were obtained by Aiedia (1995) (126.7ppm); Tolba et al. (1995) (112.0 \pm 9.97$)$; Hassan (1997) (124.73 $\pm 1.519)$ and Farag and Abd El-Fatah (2011) (142.15 \pm 9.13$)$, but lower results were recorded by El-Khateib et al. (1987) as the residual nitrite levels in pastirma were low, on average $12 \mathrm{mg} / \mathrm{kg}$. Kotzekidou (1990) Studied chemically the pastirma produced by five different plants in Greece. He found that the average of nitrite level was $100 \mathrm{ppm}$.

Table 2 showed that $65 \%$ and $85 \%$ of examined prifried and fried samples of examined pastirma not exceeded the maximum permissible limit of nitrite (100 ppm) according to E.S.S., NO. 3597/2005 for sodium nitrite in foods products. Also, it was evident that the frying heat treatment could lead to a significant reduction of residual nitrite content of pastirma $(\mathrm{p}<0.05), \quad$ (Table 3$)$ Egyptian standard specification No.3597/2005 stated $100 \mathrm{ppm}$ as the maximum permissible limit for residual nitrite in cured meat products and didn't differentiate between cooked, raw, salted and dry meat products in their residual nitrite content.

About 55\% of examined samples of retailed pastirma had lower nitrite concentrations than declared on the labels $(50 \mathrm{ppm})$, so the potential for botulinum toxin production can be exist for such samples especially this product was kept unrefrigerated, but it is recorded that the spores fail to germinate until the residual nitrite concentratin is reduced to below 4 ppm (Urbain, 1971). Current U.S.regulations allow the use of 
nitrite and nitrate in meat products based upon the product category and method of curing (IFT, 1987). Immersion cured,massaged or pumped products such as hams or pastirma are limited to a maximum ingoing level of sodium or potassium nitrite and nitrate of 200 and $700 \mathrm{ppm}$, respectively, based on the raw product weight. If a combination of nitrite and nitrate are used, the combination must not result in more than 200ppm sodium nitrite in the finished product (USDA, 1995).

\section{Beef luncheon:}

Data presented in Table 1 showed that residual nitrite content of beef luncheon in prifried samples were ranged from 31.542 to 200.818 with a mean \pm S.E.value of $97.255 \pm 12.66 \mathrm{ppm}$, but after frying were ranged from 14.72 to150.35, with a mean \pm S.E.value of $58.773 \pm 7.571$ ppm.

Aiedia (1995) stated that the residual nitrite content of beef luncheon was ranged from 75.0 to160.0 with a mean value of 118.9 ppm; also, Fath El-Bab and Sayed (2005) recorded that the nitrite concentration in beef luncheon was ranged from 110 to 128 with a mean \pm S.E.value of $120.1 \pm 1.2 \mathrm{ppm}$. El-Bassuony et al. (2010) measured the mean value of nitrite content in luncheon at zero time as $100.5 \pm 4.46$ $\mathrm{mg} / \mathrm{kg}$ and this value was significantly decreased during the chilling storage time till it reached $40.8 \pm 1.78 \mathrm{mg} / \mathrm{kg}$ at the end of the chilling storage period (4 months).

The data presented in Table 2, showed that $50 \%$ \& $90 \%$ of prifried and fried luncheon samples not exceeded the maximum permissible limit $(100 \mathrm{ppm})$ and the incidence of detection of nitrite was $100 \%$. The frying heat treatment had a highly significant reducing effect on nitrite levels in luncheon samples $(\mathrm{p}<0.05)$ (Table 3$)$.

Hotchkis and Cassens (1987) reported that USDA allows $120 \mathrm{ppm}$ nitrite level with $550 \mathrm{ppm}$ ascorbate are requested. The practice of curing with $\mathrm{NaNO}_{2}$ and packaging in vacuum may provide protection against growth of S.aureus, both by extending duration of the adjustment phase of growth and by reducing the multiplication rate during the exponential phase of growth. The magnitude of inhibition is dependent on the interaction of $\mathrm{NaNO}_{2}$ concentration, initial $\mathrm{pH}$ and $\mathrm{O}_{2}$. S.aureus metabolizes nitrite when culture aerobically, but the nitrite content of anaerobic cultures remain essentially unchanged (Buchanan and Solberg, 1972). Comminuted products such as frankfurters, bologna and other cured sausages are limited to a maximum ingoing level of $156 \mathrm{ppm}$ of sodium or potassium nitrite based on the raw weight of the meat block (USDA, 1995). 


\section{Alexandria semi-dry sausage:}

It was evident from Table 1 that residual nitrite values in semidry sausages were ranged from 6.308 to 139.836 , with a mean \pm S.E. value of $48.207 \pm 8.91 \mathrm{ppm}$ in prifried samples, while were ranged from 6.308 to 103.037 , with a mean \pm S.E. value of $38.218 \pm 6.823 \mathrm{ppm}$ in fried ones.

Higher results were recorded by Aiedia (1995), (131.6 ppm) who mentioned that $35 \% \& 50 \%$ of examined sausage samples collected from classes II\&III meat processing plants, respectively, were showed relatively high nitrite contents. On the otherside, $20 \% \& 10 \%$ of sausage samples of classes II \& III were showed relatively low nitrite contents than requested. Also, El-Bassuony et al. (2010) registrated higher residual nitrite level $(94.8 \pm 4.17 \mathrm{mg} / \mathrm{kg})$ in the examined sausages at zero time and this value was significantly decreased during chilling storage till it reached $35.1 \pm 2.06 \mathrm{mg} / \mathrm{kg}$ at the end of chilling storage period (4 months).

Table 2 pointed to that only $15 \%$ of the examined prifried sausage samples exceeded the permissible limit (100ppm) of nitrite content and this percentage was regressed to $10 \%$ after frying treatment,and the statistical analysis was ensured that the frying heat treatment had a significant effect on nitrite content in semi-dry sausages $(\mathrm{p}<0.05)$ (Table 3$)$.

The second primary use for nitrite is to inhibit $C$. botulinum growth and toxin formation, although not necessarily spore germination. Its effectiveness is affected by temperature and salt concentration. Although $50 \mathrm{ppm}(\mathrm{mg} / \mathrm{kg})$ initial nitrite levels are sufficient for the meat color desired, up to $200 \mathrm{ppm}$, depending on the country, is used for antibotulinal activity. The result has been the almost total absence of botulism in cured meat. Its effect on non-spore-formers is distinctly genus dependent. As with the organic acids, lower $\mathrm{pH}$ noticeably improves the antimicrobial activity of nitrite (Labb'E and Nolan, 2009) .

With respect to the depletion or disappearance of nitrite from some samples, it is known that cooking reduced the amount of nitrite in the food product, depending on the heat treatment and the presence of reducing substances, so that immediately after heat processing $50 \%$ or less of the original nitrite will be found. This will diminish more rapidly and completely at increased storage temperature (Ingram and Simonsen, 1980). Nordin (1969) found the rate to be proportional to its concentration and to be exponentially related to both temperature and $\mathrm{pH}$. The depletion rate doubled for every $12.2^{\circ} \mathrm{C}$ increase in temperature 
or $0.86 \mathrm{pH}$ unit decrease and was not affected by heat denaturation of ham. These relationships did not apply at room temperature unless was the product was first heat treated, suggesting that viable organisms aided in its depletion.

In Chinese-style sausage, a non-fermented product containing natural flora, the $\mathrm{pH}$ decrease remarkably slow when manufactured by using traditional processing (Chen et al., 1997). This indicated that bacteria did not degrade suger to lactic acid because of shorter fermention or non-fermentation. The maximum ingoing level of sodium nitrite permitted in Denmark is $60 \mathrm{ppm}$ for most products with some specialty products allowed to have up to $150 \mathrm{ppm}$. From 1998 to 2006, the residual nitrite in Denmark sausages and salami-type products has varied between 6-20 ppm (Leth et al., 2008) as a result of the ingoing levels allowed. In Australia, nitrites (sodium or potassium salts) are allowed at a maximum level of $125 \mathrm{ppm}$ incured, dried and slow-dried cured meat and $50 \mathrm{ppm}$ in sterile and canned meat. Nitrate may be incorporated at $500 \mathrm{ppm}$ in slow-dried cured meats (Hsu et al., 2009). Meat products surveyed in a Sydney market were found to have a nitrite content ranging from 3.7 to $86.7 \mathrm{ppm}$ while nitrate levels ranged from 3.7 to $139.5 \mathrm{ppm}$. Gangolli et al. (1994) reported the nitrite and nitrate contents of bacon in the UK to be 24 and $43 \mathrm{mg}$, respectively, while ham levels were 26 and $22 \mathrm{ppm}$, respectively. A multi-year survey of Canadian products indicated that the overall mean residual nitrite levels in cured meats had declined over the past $20-25$ years averaging $28 \mathrm{ppm}$ in 1972, 44 ppm in 1983-1985, 31 ppm in 1993-1995, and 28 ppm in 1996 (Sen and Baddoo, 1997). Finnish cured meat products have been observed to range from 2.3-31.6 and 19-136 ppm for nitrite and nitrate contents, respectively (Penttila et al., 1990).

Based on this brief overview of the nitrite in cured meat products from other countries and those values reported in Tables 1\&2, comparable Egyptian products often contain nearly the same levels. Some factors contributing to lower residual nitrite levels could be the use of reductants such as sodium ascorbate (erythorbate), depletion of nitrite during refrigerated storage and the unstable nature of the nitrite (Anonymous, 1981). Interest in the use of sorbate as a preservative in cured meat products was proposed as an alternative to the use of nitrite, which might form nitrosamines in cured meats (Robach and Sofos, 1982; Sofos and Busta, 1983). Reduced nitrite levels (40-80ppm) resulted in decreased nitrosamine formation and appear to be adequate for the other functions of nitrite (e.g.,color, flavor, rancidity prevention, 
etc.) while inclusion of sorbate in the formulation $(0.2 \%)$ can be as effective as $120 \mathrm{ppm}$ nitrite levels for control of Cl.botulinum (Sofos and Busta 1983). Another curing adjunct is phosphate, usually sodium pyrophosphate, tripolyphosphate and hexametaphosphate, they are added mainly to increase the water-holding capacity of muscle, thereby reducing shrinkage of finished products and also,as an effective antioxidant, can retard rancidity development and acting as a buffering agent to stabilize nitrite.

Finally, it is recommended that a periodic monitoring of nitrate, nitrite and nitrosamine in meat and meat products in meat plants before marketing and in the open markets, both for local and imported foods, should be permitted to the specialists, strict law enforcement should be undertaken by the governmental authorities, the primitive meat processing factories should be put under strict control of the specific food hygienic authorities and modern hurdle technology for meat and meat products preservation must be applied.

\section{REFERENCES}

Aiedia, Hoda, A. (1995): Quality investigation into room kept traditional meat products in Egypt. Ph.D.Vet. Sci. Fac. Vet. Med., Cairo Univ., Egypt.

Anonymous (1981): The health effects of nitrate, nitrite and $\mathrm{N}$ nitroso compounds. Committee on Nitrate and Alternative Curing Agents in Food. National Research Council, National Academy Press, Washington, D.

$A O A C$ (1990): Official Methods of Analysis (15 edn). Association of Official Analytical Chemists, Washington, DC, USA, method 973.31.

Buchanan, R.L. and Solberg, M. (1972): Interaction of sodium nitrate, oxygen and $\mathrm{pH}$ on Growth of Staphylococcus aureus. J. Food Sci.; 37:81-85.

Cassens, R.G. (1995): Use of sodium nitrite in cured meats today. Food Technol. 49: 72-80, 115.

Cassens, R.G. (1997): Composition and safety of cured meats in the USA. Food Chemistry; 59, 4: 561-566.

Chen, M.T.; Guo, H.L. and Liu, D.C. (1997): Volatile compounds and some properties of Chinese-style sausage. Fleischwirtsch., 77: 249-250. 
EL-Bassuony, R.A.; El-Mosalami, Eman, M.; El-Taher, Omaima, M. and El-Bakery, Z.M.A. (2010): Determination of sodium nitrite residues in some cured meat products during chilling storage at $+4^{\circ} \mathrm{C}$. Vet. Med. J. Giza.; 58: 71-79.

El-Khateib, T.; Schmidt, U. and Leistner, L. (1987): Microbiological stability of Turkish basterma. Fleischwirtschaft, 67(1): 101-105.

Egyptian Standard Specification, No. 3597/2005: for Sodium Nitrite in Food products. Egyptian Organization for Standardization and Quality Control.

Farag, H.El-S.M. and Abd-El-Fatah, Noha, R.M. (2011): Assessment of nitrite and sorbic acid salts level in some meat products and their public health significance. Ass. Vet. Med. J. 57, 129: $1-21$.

Fath El-Bab, Gehad, F.A. and Sayed, Eman, M. (2005): Some bacterial and chemical investigate ons on Chicken and beef luncheon. Vet. Med. J., Giza, 53, 3: 855-862.

Flores, J. and Toldra, F. (1993): Curing: Processes and applications. In Encyclopaedia of Food Science, Food Technology and Nutrition, eds R. Macrae, R. Robinson, M. Sadler \& G.Fullerdove. Academic Press, London, pp. 1277-1282.

Gangolli, S.D.; Van den Brandt, P.A.; Feron, V.J.; Janzowsky, C.; Koeman, J.H.; Speijers, G.J.; Spiegelhalder, B.; Walker, R. and Wishnok, J.S. (1994): Nitrate, nitrite and $N$-nitroso compounds. Eur. J. Pharmacol., Environ. Toxicol. Pharmacol. Section. 292:1-38.

Gibson, A.M. and Roberts, T.A. (1986): The effect of $\mathrm{pH}$, water activity, sodium nitrite and storage temperature on the growth of enteropathogenic Escherichia coli and Salmonellae in laboratory medium. Int. J. Food Microbiol.; 3:183.

Hassan,O.A.A.(1997): Impact of component of pastirma on its organoleptic, bacteriological and chemical status. M.V.Sc. Thesis Fac. Vet. Med., Cairo Univ., Egypt.

Hotchkis, J.H. and Cassens, R.G. (1987): Nitrate, Nitrite and Nitroso Compounds in Foods. Food Tech.; 39(1): 67.

Hsu, J.; Arcot, J. and Lee, N.A. (2009): Nitrate and nitrite quantification from cured meat and vegetables and their estimated dietary intake in Australians. Food Chem.; 115: 334-339.

IFT "Institute of Food Technologists" (1987): Nitrate, nitrite and nitroso compounds in foods. Food Technol.; 41(4): 127-136. 
Ingram, M. and Simonsen, B. (1980): Meat and meat products. In: Microbial Ecology of Foods. Vol. II, Food Commodities, ICMSF, PP. 333-409. Academic Press, New York.

Kotzekidou, P. (1990): Unpublished data, Dept. of Food Sci. \& Tech., Univ. of Thessaloniki, Greece. (Cited after Aiedia-Hoda,1995).

Kramlich, W.E.; Pearson, A.M. and Tauber, F.W. (1973): Processed Meats. AVI Publishing Co. Inc.Westport.

Labb'E, R. and Nolan, Linda L. (2009): Food preservation techniques other than heat and irradiation. In: Microbiologically Safe Foods, Chapter 24. John Willy\&Sons, INC., Publication.

Leth, T.; Fagt, S.; Nielsen, S. and Andersen, R. (2008): Nitrite and nitrate content in meat products and estimated intake in Denmark from 1998 to 2006. Food Add. Contamin. 1-9 iFirst. Accessed 7/11/2009.

McKnight, G.M.; Duncan, C.W.; Leifert, C. and Golden, M.H. (1999): Dietary nitrate in man: friend or foe? Br.J. Nutr. 81:349-358.

Moran, D.M.; Tannenbaum, S.R. andArcher, M.C. (1975): Inhibitor of Clostridium perfringen formed by heating sodium nitrite in a chemically defined medium. Appl. Microbiol.; 30: 838-843.

Muller, N.D. (1991): Curing and Smoking. Fleischwirtsch.,71(1):61-65.

Nordin, H.R. (1969): The depletion of added sodium nitrite in ham. Can. Inst. Food Sci. Technol.J.; 2: 79-85.

Pearson, A.M. and Tauber, F.W. (1996): Processed Meat. $3^{\text {rd }}$ Ed. AVI. Publishing Company Inc., West Port Connectcut.

Pelroy, G.; Peterson, M.; Paranjpye, R.; Almond, J. and Eklund, M. (1994): Inhibition of Listeria monocytogenes in cold-process (smoked) salmon by sodium nitrite and packaging material. J.Food Prot.; 57:114-119.

Penttila, P.-L.; Rasanen, L. and Kimppa, S. (1990): Nitrate, nitrite and $\mathrm{N}$-nitroso compounds in Finnish foods and the estimation of the dietary intakes. Z.Lebensm Unter Forsch.; 190:336-340.

Perigo, J.A.; Whiting, E. and Bashford, T.E. (1967): Observation on the inhibitor of vegetative cells of Clostridium sporogenes by nitrite which has been autoclaved in a laboratory medium, discussed in the context of sublethally processed cured meats. J. Food Technol. 2: 377.

Rice, K.M. and Pierson, M.D. (1982): Inhibition of Salmonella by sodium nitrite and potassium sorbate in frankfurters. J. Food Science; 47: 1615-7. 
Robach, C.C. and Sofos, J.N. (1982): Use of sorbates in meat products, fresh poultry and Poultry products: A review. J. Food Prot.; 45: 374 383.

Sen, N.P. and Baddoo, P.A. (1997): Trends in the levels of residual nitrite in Canadian cured meat products over the past 25 years. J. Agric. Food Chem.; 45: 4714-4718.

Sofos, J.N. and Busta, F.F. (1983): Sorbates. In Antimicrobials in Food. (A.Branen and M. Davidson, eds.) pp.141-176, Marcel Dekker, New York .

Tarr, H.L.A. (1942): Action of nitrates and nitrites on bacteria. J. Fish Res. Board Can.; 6:233-242.

Tolba, K.S.; Abdel-Aziz, A.S. and Niazi, Z. (1995): Chemical analysis of locally manufactured meat products . Vet. Med. J.; 42, 3: 79.

Urbain, W.M. (1971): Meat preservation. Ch 9 in:The science of meat and meat product. $2^{\text {nd }}$ Ed. J.F. Price and B.C. Schweigert (eds). pp 403-451. W.H. Freeman \& Co. San Francisco.

U.S. Department of Agriculture, Food Safety Inspection Service (1995): Processing Inspectors 'Calculations Handbook. Revised 1995. Accessed 7/26/2009.

http://www.google.com/\#hl=en\&q=usda+Processing+Inspector $\% 27 \mathrm{~s}+$ Calculation $\mathrm{s}+$ Handbook\&aq $=\mathrm{f} \&$ oq $=\&$ aqi $=\& \mathrm{fp}=\mathrm{VEE} 02$ fthf5k

Wirth, F. (1991): Restriction and dispensing with curing agents in meat products. Federal Meat Research Institute of Technology, Kulmbach. Fleishwirtschft. (71): 1051. 